\title{
Accumulation of Trace Metal in Sediment and Soft Tissue of Strombus canarium in a Tropical Remote Island of Thailand
}

\author{
Thawanrat Kobkeatthawin $^{1}$, Sanya Sirivithayapakorn ${ }^{2}$, Thongchai Nitiratsuwan ${ }^{3}$, Dudsadee Muenhor ${ }^{1,4,5}$, \\ Pei-Sun Loh ${ }^{6}$ and Siriporn Pradit $1,7, *$ (D)
}

1 Faculty of Environmental Management, Prince of Songkla University, Hat Yai 90110, Thailand; kunthidakob@gmail.com (T.K.); dudsadee.m@psu.ac.th (D.M.)

2 Environmental Engineering Department, Faculty of Engineering, Kasetsart University, Bangkok 10900, Thailand; Sanya.si@ku.ac.th

3 Faculty of Science and Fisheries Technology, Rajamangala University of Technology Srivijaya, Trang 92150, Thailand; nitiratsuwan@gmail.com

4 Health Impact Assessment Research Center, Prince of Songkla University, Hat Yai 90110, Thailand

5 Center of Excellence on Hazardous Substance Management (HSM), Bangkok 10330, Thailand

6 Institute of Marine Geology and Resources, Ocean College, Zhejiang University, Zhoushan 316021, China; psloh@zju.edu.cn

7 Coastal Oceanography and Climate Change Research Center, Faculty of Environmental Management, Prince of Songkla University, Hat Yai 90110, Thailand

* Correspondence: siriporn.pra@psu.ac.th

\section{check for} updates

Citation: Kobkeatthawin, T.; Sirivithayapakorn, S.; Nitiratsuwan, T.; Muenhor, D.; Loh, P.-S.; Pradit, S Accumulation of Trace Metal in Sediment and Soft Tissue of Strombus canarium in a Tropical Remote Island of Thailand. J. Mar. Sci. Eng. 2021, 9, 991. https://doi.org/10.3390/ jmse9090991

Academic Editors: Nathalie Fagel and Olivier Radakovitch

Received: 20 July 2021

Accepted: 8 September 2021

Published: 11 September 2021

Publisher's Note: MDPI stays neutral with regard to jurisdictional claims in published maps and institutional affiliations.

Copyright: (c) 2021 by the authors. Licensee MDPI, Basel, Switzerland This article is an open access article distributed under the terms and conditions of the Creative Commons Attribution (CC BY) license (https:// creativecommons.org/licenses/by/ $4.0 /)$
Abstract: The present study determined the metal levels in surface sediment and in soft tissue of the Strombus canarium at Libong Island, Thailand, and estimated the possible risk from consuming the shellfish. The mean concentrations of the metals $\mathrm{Fe}, \mathrm{Cu}, \mathrm{Co}, \mathrm{Pb}, \mathrm{Mn}$, and $\mathrm{Ni}$ in sediment were $2711.94 \pm 1424.83,0.47 \pm 0.37,0.11 \pm 0.09,1.32 \pm 1.48,40.41 \pm 16.12$, and $2.75 \pm 4.04 \mu \mathrm{g} / \mathrm{g}$, respectively, and are below the sediment quality guidelines. The enrichment factor (EF) and geoaccumulation index (Igeo) showed that the sediment conditions ranged from "no pollution" to "moderate contamination". The mean concentrations in Strombus canarium had rank order Fe $>\mathrm{Mn}>\mathrm{Cu}>\mathrm{Ni}$ $>\mathrm{Co}>\mathrm{Pb}$. The bioaccumulation (BSAF) suggests that the Strombus canarium accumulated $\mathrm{Cu}$ and Co the most. The estimated daily intakes of these metals through shellfish consumption were below the oral reference dose (Rfd) and the calculated target hazard quotients (THQ) were less than 1 . The results from this study inform about the background levels of metals in the sediment and in Strombus canarium species at Libong Island. In addition, these data might help ensure that the consumption of shellfish in this area remains safe.

Keywords: trace metal; surface sediment; Strombus canarium; bioaccumulation (BSAF); human consumption risk

\section{Introduction}

In recent decades, environmental pollution in the coastal seas has received increasing attention, not only because of the effects on ecosystems, but also on human health. Among the various types of pollution, trace metal contaminants have become a serious problem because of their toxicity, persistence, and hazardous bioaccumulation in the food chains of an aquatic ecosystem [1-4]. Most of these trace metals, copper ( $\mathrm{Cu})$, cobalt (Co), iron (Fe), nickel $(\mathrm{Ni})$, lead $(\mathrm{Pb})$, and manganese $(\mathrm{Mn})$ are listed as priority pollutants to be monitored by the US Environmental Protection Agency (U.S. EPA) [5]. High concentrations of trace metals could have adverse health effects on living organisms, not only on aquatic animals, but also on humans who consume contaminated seafood. Recently, Pereira and coworkers studied toxicokinetics in context of the central nervous system and sensory organs of fish exposed to $\mathrm{Hg}$, and the effects on mammals [6]. In addition, many previous studies have shown that trace metals are transported into body cells of humans, and can cause 
neurological changes, cancer, Alzheimer's disease, and cardiovascular diseases [7-9]. It is well known that the sediments in a water body serve as both a sink and a source of trace metals, and most of the trace metals loaded in aquatic systems are related to suspended particulate matter and sediments [10,11].

The wing shell (Strombus canarium) is an economically important mollusk in the Indo-Pacific region, which is widely distributed in Myanmar [12], Malaysia [13], Southern India [14], Sri Lanka [15], and along the Andaman sea of Thailand [16]. It is a popular seafood item consumed by villagers in the Andaman Sea region and by domestic and foreign tourists, because the soft tissue of Strombus canarium is delicious and a high quality protein, and the catches can generate considerable amounts of income to fishermen. Strombus canarium, also known as live in various types of habitats. Generally, this species is present in mudflats and seagrass bed areas, along the coastlines of Libong Island, Thailand. This island has a diverse ecosystem, including coral reefs, mangrove forests, and an extensive seagrass bed. In addition, it is the habitat of dugongs. Since Strombus canarium is a filter-feeder organism similar to cockles and mussels, contamination of the highly productive mudflats with metals leads to accumulation throughout the body tissue [17]. Recently, concerns have been raised about possible trace metal contamination in the coastal areas of Thailand, especially around Libong Island. An increasing number of tourists are visiting this island to observe the dugong and enjoy seafood, particularly wing shell meals. Recently, Pradit et al. 2020 reported on marine waste and hazardous waste, including batteries, on Libong Island, which were released from the mainland [18]. Moreover, activities around Libong Island, such as household activities, tourism, rubber industry, and agricultural activities, could be sources of trace metals that may affect aquatic animals and humans who consume the shellfish contaminated with trace metals.

Thus, the aim of this study was to assess the accumulation of trace metals $(\mathrm{Fe}, \mathrm{Cu}, \mathrm{Co}$, $\mathrm{Pb}, \mathrm{Mn}$, and $\mathrm{Ni}$ ) in surface sediments and in the soft tissues of the Strombus canarium at Libong Island, Thailand, and assess potential risks to humans from consuming this shellfish. In addition, our investigation is the first study regarding trace metal contamination on Libong Island. The study results will be used as baseline data for the present state of metal in sediment and in shellfish in the region. In addition, this information is very important for better management of this Island in the future.

\section{Materials and Methods}

\subsection{Study Area}

The study site is situated on the east coast of Libong Island. It is located at latitude $07^{\circ} 14^{\prime}-07^{\circ} 17^{\prime} \mathrm{N}$ and longitude $99^{\circ} 22^{\prime}-09^{\circ} 27^{\prime} \mathrm{E}$, in Trang province, Thailand (Figure 1). There are four villages and an estimated 717 people who live in this area; the majority are involved with fishing, tourism, and agricultural activities. The area of Libong Island consists of coral reef, mangrove forests, and seagrass bed, which have high biodiversity and abundance. Thus, this is an important food source of dugongs and many other aquatic species, especially the Strombus canarium. In addition, this ecological system is very delicate and sensitive to marine waste pollution. The selected stations are covered with sandy beach (stations 1-9) next to mud flats (stations 10-33) and seagrass plants (found around stations 7,8 , and 9).

\subsection{Sample Collection and Storage}

\subsubsection{Sediment Samples}

The surface sediments were collected from 33 stations (Figure 1) on May 2019, near the shore (stations 1-9) where the sediment type has more sand than mud, and further away from the shore (about $500 \mathrm{~m}$, stations 10-33) where the sediment type is muddy. Quadrant frames $(50 \times 50 \mathrm{~cm})$ were used for sampling the surface sediment in each block. The sediment was collected using a shovel, by scooping to about a $10 \mathrm{~cm}$ depth, and placing the samples in plastic Ziploc bags. The samples were transported immediately to the laboratory and preserved at $-20^{\circ} \mathrm{C}$ for later analysis. The wet sediments were air-dried, 
ground with a mortar and pestle, and sieved through a $1 \mathrm{~mm}$ nylon sieve to obtain a fine homogeneous powder before analysis.
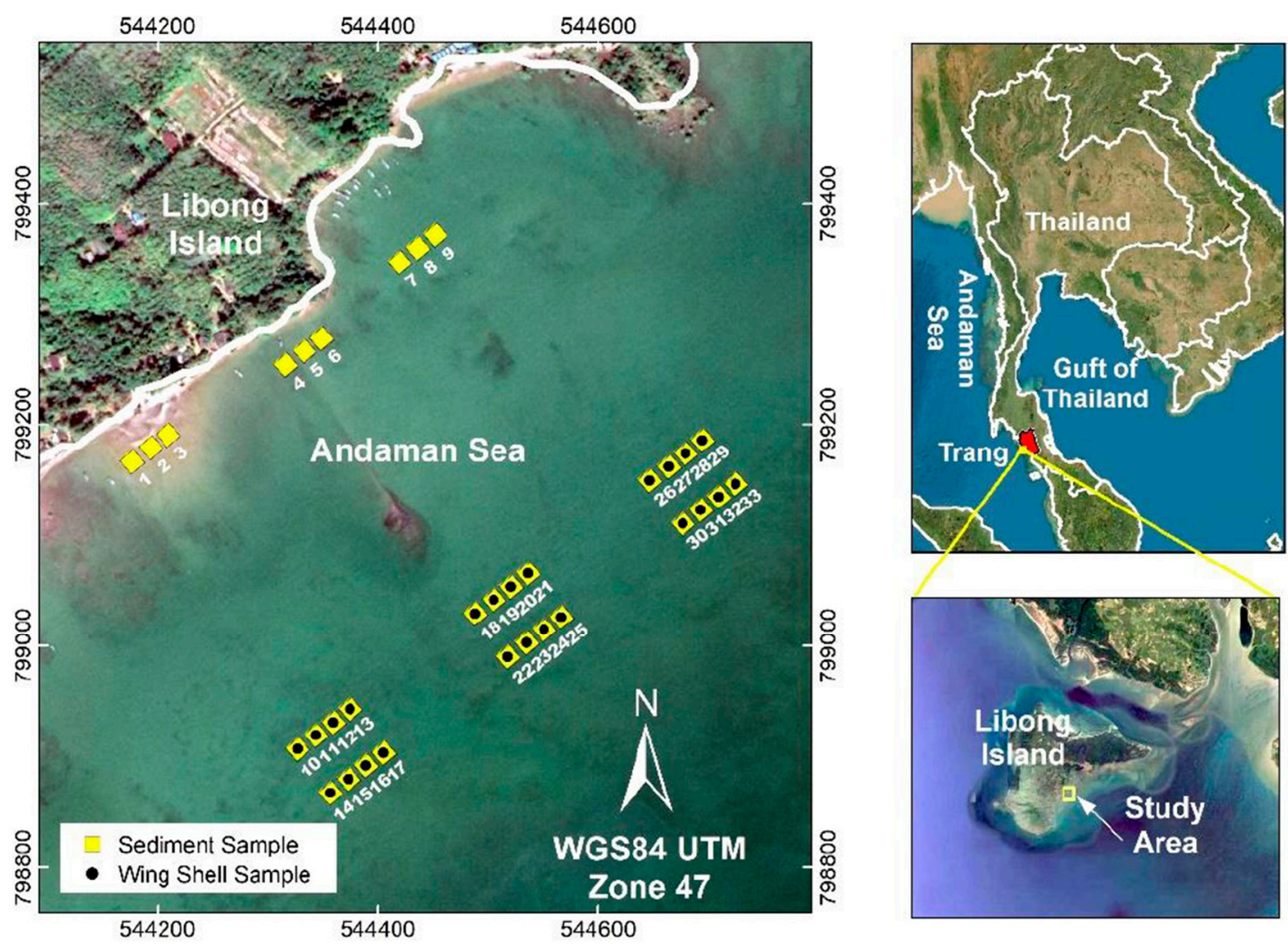

Figure 1. Sampling stations at Libong Island, Thailand.

\subsubsection{Biological Samples}

Strombus canarium samples were collected from Libong Island in the same period (Figure 1). A total of 35 Strombus canarium samples were bought from the local people who handpicked them from the mud flats in the study area. It was reported that Strombus canarium can reproduce all year round, but a high growth rate and a good survival rate prevail in the wet season [13]. Thus, the studied samples were collected in May, which is at the start of the wet season on Andaman Sea, Thailand. The Strombus canarium samples were kept in clean plastic bags and were transported immediately to the laboratory in an icebox and then kept at $-10^{\circ} \mathrm{C}$. Before analysis, the samples were cleaned with distilled water. In addition, the total lengths, weights, and fresh tissue of the Strombus canarium samples were measured. Then, the soft tissue was dried at $60{ }^{\circ} \mathrm{C}$ in an oven and ground to a fine powder with a mortar and pestle.

\subsection{Digestion Procedure}

\subsubsection{Sediment Samples}

Sample preparation and analysis procedures was performed according to the U.S. EPA [19] and Pradit et al., (2010) [20]. Approximately, $0.1 \mathrm{~g}$ of sediment (dw) was weighed in the Teflon digestion vessel before being digested with $2 \mathrm{~mL}$ of $\mathrm{HNO}_{3}(65 \%$, Merck, Suprapur) and $6 \mathrm{~mL} \mathrm{HCl} \mathrm{(30 \% ,} \mathrm{Merck,} \mathrm{Suprapur).} \mathrm{The} \mathrm{samples} \mathrm{were} \mathrm{heated} \mathrm{in} \mathrm{an} \mathrm{oven} \mathrm{at}$ $120^{\circ} \mathrm{C}$ for $7 \mathrm{~h}$. After cooling to room temperature, the digested solution was filtered by using Whatman No. 1 paper. Then, $30 \mathrm{~mL}$ of Milli-Q water was added and the samples were stored in acid-cleaned polyethylene storage bottles before analysis (60 mL, Nalgene). 


\subsubsection{Biological Samples}

Digestion of Strombus canarium was conducted according to the U.S. EPA [19] and Pradit et al. [20]. A dry soft tissue sample $(0.05 \mathrm{~g})$ was transferred to a Teflon digestion vessel for acid digestion using $1.5 \mathrm{~mL} \mathrm{HNO}_{3}(65 \%$, Merck). Samples were digested similarly as the sediment. After cooling to room temperature, the samples were filtered through Whatman No. 1 paper. Then, the obtained solution was diluted to $10 \mathrm{~mL}$ with Milli-Q water and stored in polyethylene storage bottle for analysis.

\subsection{Analysis of Metals}

All equipment used for sample preparation and analysis was soaked in nitric acid ( $3 \%$, Merck) overnight and then rinsed several times with Milli-Q deionized water prior to use. All used reagents were of analytical grade. Analytical data quality controls were performed using calibration curves prepared from multi-element (Merck) or single element (Johnson Matthey Specpure) internal standard solutions [21,22]. The minimum correlation coefficient of the calibration curve accepted was 0.999. Blank samples were also prepared for each set by using the digestion acids mixture used above without adding a sample. Trace metal concentrations were analyzed with an Inductively Coupled Plasma-Mass Spectrometer (ICP-MS, Shimadzu ICP-MS-2030LF). The efficiency of the analysis was assessed by three replicates. The detection limit was $0.1 \mathrm{mg} / \mathrm{kg}$ for $\mathrm{Fe}, \mathrm{Cu}, \mathrm{Co}, \mathrm{Mn}, \mathrm{Ni}$, and $\mathrm{Pb}$.

\subsection{Data Processing and Statistical Analysis}

All calculations and statistics were carried out using MS Excel 2007 (Office Professional Plus 2019) software. Pearson correlation analysis was employed to test the relationship of trace metals in Strombus canarium, and weight, and statistical significance required a 95\% confidence level $(p<0.05)$ or a $99 \%$ confidence level $(p<0.01)$.

\subsubsection{The Enrichment Factor (EF)}

The enrichment factor (EF) was used to assess metal accumulation compared to the average occurrence of that metal in the Earth's crust [23], and was calculated by Equation (1).

$$
\mathrm{EF}=\left(\mathrm{M}_{\text {sample }} / \mathrm{Fe}_{\text {sample }}\right) /\left(\mathrm{M}_{\text {background }} / \mathrm{Fe}_{\text {background }}\right)
$$

Here, $\mathrm{M}_{\text {sample }}$ and $\mathrm{Fe}_{\text {sample }}$ are the sediment sample concentrations of the trace metal and $\mathrm{Fe}$, whereas $\mathrm{M}_{\text {background }}$ and $\mathrm{Fe}_{\text {background }}$ are background concentrations of the trace metal and Fe [24]. Fe was used to normalize the trace metals in the sediment because it is a conservative element in the Earth [25]. The regional background values used in this study were those reported from offshore sediments in the Gulf of Thailand by Shazili et al. [26] and Taylor and Mclennan [27]. The background concentrations were 12,200 $\mu \mathrm{g} / \mathrm{g}$ for Fe, $12.7 \mu \mathrm{g} / \mathrm{g}$ for $\mathrm{Cu}, 15 \mu \mathrm{g} / \mathrm{g}$ for Pb, $104 \mu \mathrm{g} / \mathrm{g}$ for $\mathrm{Mn}, 10 \mu \mathrm{g} / \mathrm{g}$ for Co and $20 \mu \mathrm{g} / \mathrm{g}$ for $\mathrm{Ni}[26,27]$. If $\mathrm{EF}<1$ there is "no enrichment" of the metal; $\mathrm{EF} 1$ to 3 is for "minor enrichment"; EF 3 to 5 for "moderate enrichment"; EF 5 to 10 for "moderately severe enrichment"; EF 10 to 25 for "severe enrichment"; EF 25 to 50 for "very severe enrichment" and EF > 50 for "extremely severe enrichment" [28].

\subsubsection{The Geoaccumulation Index (Igeo)}

The geoaccumulation index (Igeo) was used to assess the metal contamination caused by both natural events and anthropogenic activities [29]. This value was calculated according to Equation (2), as introduced by Muller [30].

$$
\text { Igeo }=\log 2 \mathrm{Cn} / 1.5 \times \mathrm{Bn}
$$

Here, $\mathrm{Cn}$ is the measured concentration of the sediment for a trace metal, $\mathrm{Bn}$ is the geochemical background concentration of the trace metal, and 1.5 is the correction factor for variation in the background value because of lithogenic effects [30]. If Igeo $>5$, then the result is "extremely contaminated"; $4-5$ for "strongly to extremely contaminated"; 
3-4 for "strongly contaminated"; 2-3 for "moderately to strongly contaminated"; 1-2 for "moderately contaminated"; 0-1 for "uncontaminated to moderately contaminated", and $<0$ for "uncontaminated" [31].

\subsubsection{Biota-Sediment Accumulation Factor (BSAF)}

Biota-sediment accumulation factor (BSAF) was used to assess the trace metal accumulation abilities in the target organism from that of the associated sediment [32,33]. BSAF was calculated according to Equation (3).

$$
\mathrm{BSAF}=\mathrm{Ct} / \mathrm{Cs}
$$

Here, $\mathrm{Ct}$ and $\mathrm{Cs}$ are the mean metal concentrations in tissue and in sediment, respectively. The BSAF values can be classified into three groups "macroconcentrator" (BSAF > 2), "microconcentrator" (1 < BSAF < 2), and "deconcentrator" (BSAF < 1) [34].

\subsubsection{The Conversion Factor (CF)}

The trace metal concentrations by dry weight were converted to wet weight to compare with the permissible limits, by following guidelines by Yap and coworkers, as in Equation (4).

$$
\mathrm{Mc}(\text { wet })=\mathrm{CF} \times \mathrm{Mc}(\mathrm{dry})
$$

Here, Mc(wet) is the wet weight-based metal concentration, Mc(dry) is the dry weightbased metal concentration, and CF is the conversion factor, namely wet weight/dry weight ratio, taken as 0.26 in this study [35].

\subsubsection{Estimated Daily Intake (EDI)}

The estimated daily intakes (EDI) were calculated based on trace metal concentration in the targeted shellfish samples and on the average daily shellfish consumption rate in Equation (5) [36].

$$
\mathrm{EDI}=(\mathrm{Mc}(\text { wet }) \times \mathrm{Wfood}) / \mathrm{BW}
$$

Here, $\mathrm{Mc}$ (wet) is the wet weight-based metal concentration in contaminated shellfish $(\mathrm{mg} / \mathrm{kg})$, Wfood is the daily average consumption of shellfish by a Thai person (135 g/day) [37], and BW is the body weight of a single people in the range of 14-60 years of age (the normal average body weight is $60 \mathrm{~kg}$ in Thailand) [37].

\subsubsection{The Target Hazard Quotient (THQ)}

The target hazard quotient (THQ) was calculated using the following Equation (6) [38].

$$
\mathrm{THQ}=\mathrm{EDI} / \mathrm{Rfd}
$$

Here EDI is the estimated daily intake ( $\mathrm{mg} / \mathrm{kg}$ bw/day) and $\mathrm{Rfd}$ is the oral reference dose of the trace element according to the US EPA ( $\mathrm{mg} / \mathrm{kg}$ bw/day) [39].

\section{Results and Discussion}

\subsection{Concentrations of Trace Metals in Surface Sediment}

Table 1 summarized the minimum, maximum, and average concentrations of the six trace metals in the surface sediment from Libong Island, with comparisons to other published studies. The trace metals observed had wide variations in concentrations, with $\mathrm{Fe}, \mathrm{Cu}, \mathrm{Co}, \mathrm{Pb}, \mathrm{Mn}$, and Ni ranges $1264.00-5711.00 \mu \mathrm{g} / \mathrm{g}, 0.10-1.34 \mu \mathrm{g} / \mathrm{g}, 0.10-0.42 \mu \mathrm{g} / \mathrm{g}$, $0.18-7.69 \mu \mathrm{g} / \mathrm{g}, 20.06-82.79 \mu \mathrm{g} / \mathrm{g}$, and $0.42-22.88 \mu \mathrm{g} / \mathrm{g}$, respectively. The mean $\pm \mathrm{SD}$ concentrations of $\mathrm{Fe}, \mathrm{Cu}, \mathrm{Co}, \mathrm{Pb}, \mathrm{Mn}$, and $\mathrm{Ni}$ were $2711.94 \pm 1424.83,0.47 \pm 0.37$, $0.11 \pm 0.09,1.32 \pm 1.48,40.41 \pm 16.12$, and $2.75 \pm 4.04 \mu \mathrm{g} / \mathrm{g}$, respectively. Overall, the average concentrations of trace metals in the surface sediments had the rank order $\mathrm{Fe}>\mathrm{Mn}>\mathrm{Ni}>\mathrm{Pb}>\mathrm{Cu}>\mathrm{Co}$. High concentrations of Fe and Mn were found in this area, consistent with previous studies (Table 1). It is possible that the soil in this area has a 
presence of ferromanganese crust [40]. However, the sediments of Libong Island still did not have much trace metals accumulate when compared worldwide to many coastal areas, except for $\mathrm{Pb}$ and $\mathrm{Mn}$, which had higher concentrations than many coastal areas of Iran [41,42]. It might be that, while the study area is located on a National Marine park, anthropogenic activities in households and agriculture around the park might contribute trace metal contamination to this area. Recently, Pradit et al. reported on marine waste, such as ceramic garbage, microplastic, batteries, etc., being released from the communities on Libong Island, due to influences of monsoon winds from May to October [18]. Thus, it might be that pollution from the mainland is released and transported by the seawater, and accumulates in the sediments at this remote location.

Table 1. Trace metal concentrations in surface sediments ( $\mu \mathrm{g} / \mathrm{g}$ by dry weight) at Libong Island with comparisons to prior published studies.

\begin{tabular}{|c|c|c|c|c|c|c|c|c|}
\hline \multirow{2}{*}{ Locations } & \multirow{2}{*}{ Values } & \multicolumn{6}{|c|}{ Metal Concentration $(\mu \mathrm{g} / \mathrm{g}$, Dry Weight) } & \multirow{2}{*}{ Ref } \\
\hline & & $\mathbf{F e}$ & $\mathrm{Cu}$ & Co & $\mathbf{P b}$ & Mn & $\mathbf{N i}$ & \\
\hline \multirow{4}{*}{ Libong Island, Thailand } & Mean & 2711.94 & 0.47 & 0.11 & 1.32 & 40.41 & 2.75 & \multirow{4}{*}{$\begin{array}{l}\text { This } \\
\text { study }\end{array}$} \\
\hline & S.D. & 1428.83 & 0.37 & 0.09 & 1.48 & 16.12 & 4.04 & \\
\hline & Min & 1264.00 & 0.10 & 0.10 & 0.18 & 20.06 & 0.42 & \\
\hline & Max & 5711.00 & 1.34 & 0.42 & 7.69 & 82.79 & 22.88 & \\
\hline Kharg coral, Iran & Mean & - & 16.40 & 6.60 & 0.72 & 14.40 & 18.20 & \multirow{2}{*}{ [41] } \\
\hline Lark coral, Iran & Mean & - & 5.00 & 4.00 & 0.35 & 5.00 & 8.40 & \\
\hline Hormuz, Iran & Mean & $32,555.00$ & 2.03 & 1.09 & 0.49 & 4.87 & 17.25 & \multirow{4}{*}{ [42] } \\
\hline Lark, Iran & Mean & $33,699.00$ & 3.93 & 2.10 & 0.63 & 7.52 & 33.91 & \\
\hline Qeshm, Iran & Mean & $34,935.00$ & 2.44 & 1.31 & 0.53 & 5.41 & 19.49 & \\
\hline Hengam, Iran & Mean & $30,553.00$ & 4.78 & 2.32 & 0.75 & 7.92 & 28.07 & \\
\hline $\begin{array}{l}\text { Thondi Coast, } \\
\text { India }\end{array}$ & Mean & $52,802.30$ & 54.70 & - & 14.1 & 686.1 & 27.7 & [43] \\
\hline Hainan island, china & Mean & - & 14.97 & 13.21 & 26.82 & - & 25.26 & [44] \\
\hline $\begin{array}{l}\text { Arabian Gulf, Saudi } \\
\text { Arabia }\end{array}$ & Mean & 8474.21 & 297.29 & 4.01 & 5.25 & 111.57 & 77.07 & [45] \\
\hline Gulf of Thailand & Mean & - & 12.25 & - & 21.35 & - & - & [46] \\
\hline Xiamen Bay, China & Mean & $32,783.00$ & 52.51 & 19.87 & 37.49 & 674.00 & 23.93 & [47] \\
\hline Bohai Sea, china & Mean & $13,000.00$ & 16.84 & 7.69 & 11.36 & 502.96 & 18.50 & [48] \\
\hline Gulf of Thailand & Mean & $17,860.00$ & 7.41 & - & 1.81 & - & - & [49] \\
\hline Mediterranean Sea, Egypt & Mean & $13,256.00$ & 8.46 & 8.24 & 13.17 & 381.00 & 25.93 & {$[50]$} \\
\hline Egyptian Red Sea Coast & Mean & 3490.00 & 1.94 & 9.69 & 3.26 & 127.08 & 11.40 & [51] \\
\hline $\begin{array}{l}\text { Selangor, } \\
\text { Malaysia }\end{array}$ & Mean & - & 24.89 & - & 96.02 & 219.10 & 13.90 & [52] \\
\hline Gulf of Gemlik, Turkey & Mean & $44,000.00$ & 41.00 & 19.00 & 29.00 & 634.00 & 110.00 & [53] \\
\hline
\end{tabular}

\subsection{The Spatial Distribution of Trace Metals}

The spatial distribution pattern is a powerful tool for identifying the contamination hotspots and possible sources of trace metals. The spatial distributions of the trace metals $(\mathrm{Fe}, \mathrm{Cu}, \mathrm{Co}, \mathrm{Pb}, \mathrm{Mn}$, and $\mathrm{Ni}$ ) are shown in Figure 2. The ecosystems in this study area can be divided into sandy beach, mud flats, and seagrass plants. It is interesting that high concentrations of $\mathrm{Fe}, \mathrm{Cu}, \mathrm{Mn}$, and $\mathrm{Co}$ elements tended to be associated with sediments, especially in the seagrass bed area (Stations 7, 8, and 9). Generally, $\mathrm{Fe}, \mathrm{Cu}$, and $\mathrm{Mn}$ are essential nutrients, and play important roles to seagrass growth $[54,55]$. In addition, seagrass beds can act as trace metal reservoirs that accumulate pollutants to their environmental 
concentrations [56,57]. These phenomena possibly explain the high contents of $\mathrm{Fe}, \mathrm{Cu}, \mathrm{Mn}$, and $\mathrm{Co}$ in the seagrass bed area. Accordingly, sediment samples from the sandy beach had a higher content of Fe. One possible reason is that $\mathrm{Fe}$ is an abundant transition metal in the Earth's crust and present in most rocks and soil types. Overall, most of the high levels of these metals were associated with sediments from the mudflat. It is well known that mudflat sediments contain clay particles with large specific surfaces. The surfaces of clay particles are negatively charged and can adsorb trace metals, and tend to be deposited into coastal areas and estuaries [58].

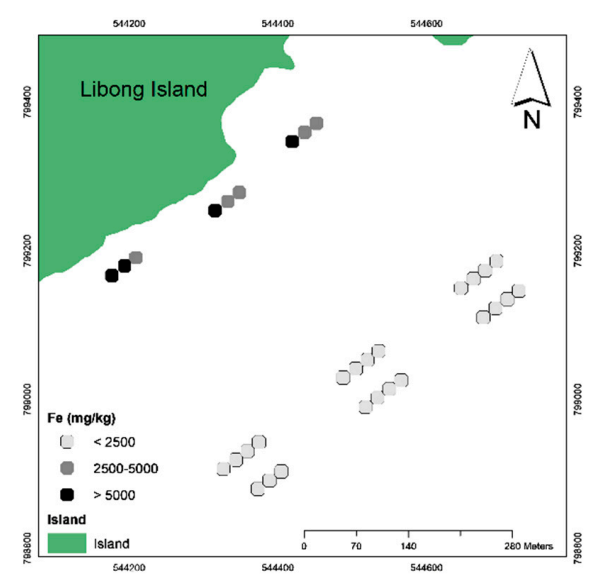

(a)

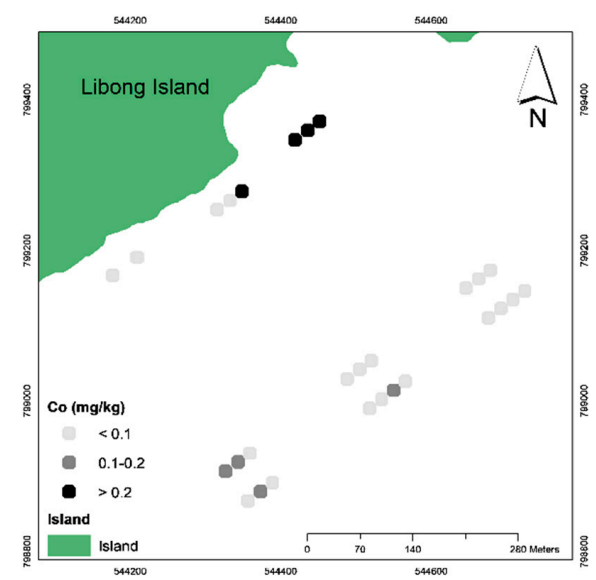

(c)

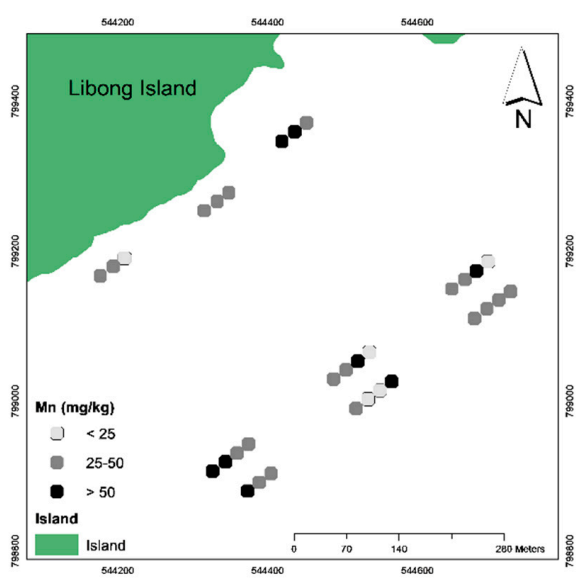

(e)

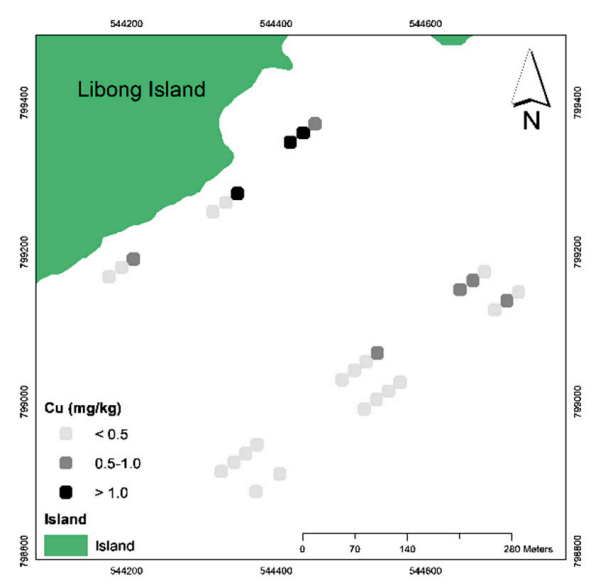

(b)

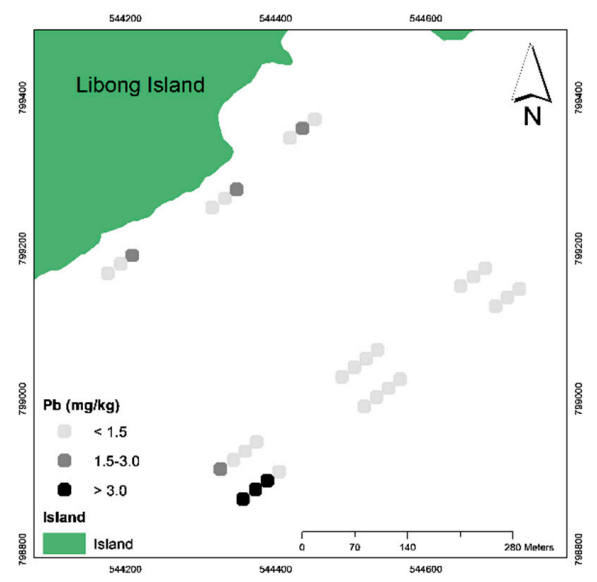

(d)

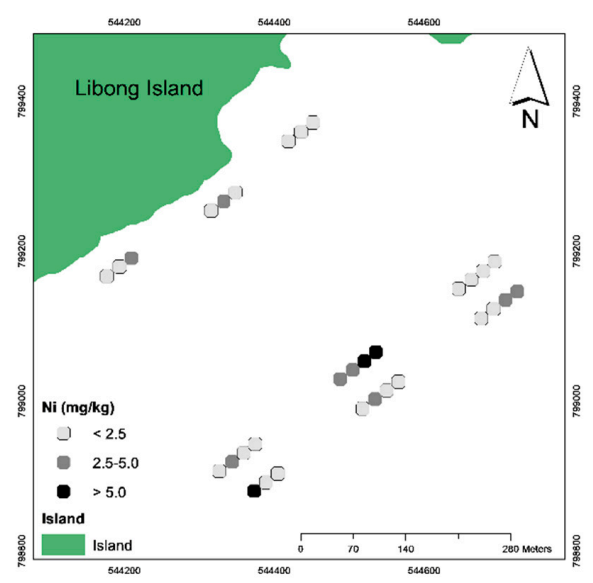

$(\mathbf{f})$

Figure 2. The trace metal distribution at Libong Island when (a) $\mathrm{Fe}$, (b) $\mathrm{Cu},(\mathbf{c}) \mathrm{Co}$, (d) $\mathrm{Pb}$, (e) $\mathrm{Mn}$, and (f) Ni. Noted: detection limit of $\mathrm{Fe}, \mathrm{Cu}, \mathrm{Co}, \mathrm{Mn}, \mathrm{Pb}$, and $\mathrm{Ni}$ is $0.1 \mathrm{mg} / \mathrm{kg}$. 


\subsection{Environmental Risk Assessment of Trace Metals in Surface Sediment}

To assess the possible toxicity levels of the trace metals in sediments, three sets of sediment quality guideline (SQGs) were used to evaluate the collected samples (Table 2). Our assessment of sediment contamination was based on US EPA sediment quality guidelines [59], the effect range low (ERL)/effect range median (ERM) [60], and threshold effect level (TEL)/probable effect level (PEL) [61]. A comparison of the SQGs indicates that the concentrations of $\mathrm{Cu}, \mathrm{Pb}, \mathrm{Mn}$, and $\mathrm{Ni}$ did not pose any environmental risks at any sampling location. Integration of additional tools, such as enrichment factor (EF), and the geoaccumulation index (Igeo) is highly recommended in order to assess the degree of contamination in sediments. The levels of EF and Igeo of trace metals in surface sediments are displayed in Table 3.

Table 2. Sediment quality guidelines (SQGs) for the analyte metals.

\begin{tabular}{|c|c|c|c|c|c|c|c|}
\hline \multirow{2}{*}{ Metals } & \multicolumn{3}{|c|}{ US EPA } & \multicolumn{2}{|c|}{$\begin{array}{c}\text { Canadian Sediment Quality } \\
\text { Guidelines }\end{array}$} & \multicolumn{2}{|c|}{ NoAA } \\
\hline & $\begin{array}{c}\text { Non- } \\
\text { Polluted }\end{array}$ & $\begin{array}{c}\text { Moderately } \\
\text { Polluted }\end{array}$ & $\begin{array}{l}\text { Heavily } \\
\text { Polluted }\end{array}$ & TEL & PEL & ERL & ERM \\
\hline $\mathrm{Fe}(\%)$ & - & - & - & - & - & - & - \\
\hline $\mathrm{Cu}$ & $<25$ & $25-50$ & $>50$ & 18.7 & 108.2 & 34 & 270 \\
\hline Co & - & - & - & - & - & - & - \\
\hline $\mathrm{Pb}$ & $<40$ & $40-60$ & $>60$ & 30.2 & 112.0 & 46.7 & 218.0 \\
\hline Mn & $<300$ & $300-500$ & $>500$ & - & - & - & - \\
\hline $\mathrm{Ni}$ & $<20$ & $20-50$ & $>50$ & 15.9 & 42.8 & 20.9 & 15.9 \\
\hline
\end{tabular}

Table 3. The Enrichment factors (EF) and geoaccumulation indexes (Igeo) of surface sediments.

\begin{tabular}{ccccccccccc}
\hline \multirow{2}{*}{ Values } & \multicolumn{4}{c}{ Enrichment Factor (EF) } & \multicolumn{4}{c}{ Geoaccumulation Index (Igeo) } \\
\cline { 2 - 11 } & $\mathbf{C u}$ & $\mathbf{C o}$ & $\mathbf{P b}$ & $\mathbf{M n}$ & $\mathbf{N i}$ & $\mathbf{C u}$ & $\mathbf{C o}$ & $\mathbf{P b}$ & $\mathbf{M n}$ & $\mathbf{N i}$ \\
\hline Mean & 0.18 & 0.06 & 0.50 & 2.48 & 1.16 & 0.04 & 0.01 & 0.10 & 0.50 & 0.18 \\
S.D. & 0.13 & 0.03 & 0.55 & 1.13 & 1.78 & 0.03 & 0.01 & 0.11 & 0.23 & 0.36 \\
Min & 0.02 & 0.00 & 0.06 & 0.63 & 0.07 & 0.00 & 0.00 & 0.01 & 0.13 & 0.00 \\
Max & 0.52 & 0.12 & 2.68 & 5.46 & 10.13 & 0.10 & 0.03 & 0.54 & 1.10 & 2.03 \\
\hline
\end{tabular}

The EF values of trace metals in this study varied as follows: $0.02-0.52$ (mean $=0.18$ \pm 0.13 ) for $\mathrm{Cu}, 0.00-0.12$ (mean $=0.06 \pm 0.03$ ) for $\mathrm{Co}, 0.06-2.68$ (mean $=0.50 \pm 0.55)$ for $\mathrm{Pb}, 0.63-5.46($ mean $=2.48 \pm 1.13)$ for $\mathrm{Mn}$ and $0.07-10.13($ mean $=1.16 \pm 1.78)$ for $\mathrm{Ni}$ (Table 3). The average EF values of $\mathrm{Cu}, \mathrm{Co}$, and $\mathrm{Pb}$ were less than 1 . These indicate no enrichment at the sampling stations. In contrast, $\mathrm{Mn}$ and $\mathrm{Ni}$ were higher than 1 , which indicates minor enrichment. According to Zhang and Liu, elements with EF between 0.5 and 1.5 are considered to originate from the crustal materials or natural processes, while those elements with EF $>1.5$ are most attributable to human activities [62]. Mn occurs naturally in sediments because of the weathering of the parent material [63]. However, human activities, such as wastewater discharges and batteries, and agricultural activities, such as rubber plantations, may contribute to the trace metal deposition in the coastal areas, causing the high Mn contents in sediments.

The Igeo values of trace metals in this study varied as follows: 0.00-0.10 (mean $=0.04$ \pm 0.03 ) for $\mathrm{Cu}, 0.00-0.03$ (mean $=0.01 \pm 0.01$ ) for $\mathrm{Co}, 0.01-0.54$ (mean $=0.10 \pm 0.11$ ) for $\mathrm{Pb}$, $0.13-1.10$ (mean $=0.50 \pm 0.23$ ) for $\mathrm{Mn}$ and 0.00-2.03 (mean = $0.18 \pm 0.36)$ for Ni (Table 3). The Igeo results show that all of the sampling stations can be classified as "no pollution" to "moderately contaminated" $(0<$ Igeo $<1)$. The highest Igeo was found for Mn. This suggests that the content of Mn has increased as a result of some anthropogenic activities. 


\subsection{Concentrations of Trace Metals in Strombus canarium}

Accumulation of trace metals in the soft tissue of Strombus canarium was compared with other species of mollusks collected from various areas of the world (Table 4). In these studies, the metal concentrations were quantified based on tissue dry weights. Wide ranges of trace metal concentrations were observed as follows: Fe, 0.00-864.50; $\mathrm{Cu}, 0.00$ $58.93 ; \mathrm{Co}, 0.00-0.92 ; \mathrm{Pb}, 0.00-2.06 ; \mathrm{Mn}, 0.00-67.72$, and $\mathrm{Ni}, 0.00-1.38 \mu \mathrm{g} / \mathrm{g}$ by dry weight. The relative average concentration of trace metals in soft tissue of Strombus canarium decreased in the order $\mathrm{Fe}>\mathrm{Mn}>\mathrm{Cu}>\mathrm{Ni}>\mathrm{Co}>\mathrm{Pb}$. Among these metals, $\mathrm{Fe}, \mathrm{Cu}$, and $\mathrm{Mn}$ have average concentrations in the same range with the other locations. In contrast, $\mathrm{Co}, \mathrm{Ni}$, and $\mathrm{Pb}$ concentrations exhibited less accumulation than in other places. In addition, our results are in agreement with those of previous studies, confirming that many species of mollusks are able to accumulate high contents of $\mathrm{Fe}, \mathrm{Mn}$, and $\mathrm{Cu}$ in their bodies (Table 4). This might be due to the tendency of mollusks to accumulate essential elements for cell growth and metabolism. It is well known that Fe is an essential element in many enzyme reactions. Ferritin is an iron storage form in living cells, which plays an important role in the intracellular iron homeostasis of mollusks $[64,65]$. Mn is a cofactor in many enzymes, including arginase, glutamine synthetase (GS), pyruvate carboxylase, and Mn superoxide dismutase (Mn-SOD) [66]. However, an excess of essential and non-essential trace elements could affect aquatic animals negatively and cause human health risks from shellfish consumption. Previous studies have shown that excessive Fe exposure can result in gastrointestinal effects, lethargy, tachycardia, hepatic necrosis, and lung cancer [67]. Ni exposure can result in fibrosis, tumors, lung inflammation, and emphysema [68]. A negative effect of Mn on human health is via neurologic and psychological disorders [69]. Although copper is one of the essential metals, a high intake of $\mathrm{Cu}$ can cause anemia, neutropenia, osteoporosis, stomach cramps, and Wilson disease [70,71]. High levels of Co can cause hematological, cardiovascular, immunological, and neurological effects [72]. In addition, $\mathrm{Pb}$ is a non-essential element that is very toxic to humans, especially to children. $\mathrm{Pb}$ can damage the kidneys, nervous, and reproductive system [73], and it can cause neurotoxicity, anemic conditions, and fatigue [74]. However, concentrations of the metals in Strombus canarium might depend on habitat. Strombus canarium is a deposit feeder consuming algae, zooplankton, and particles on the sediment surface [75]. Thus, the trace metal accumulation in deposit feeders would be expected to relate to metal concentrations in the sediments.

Table 4. Concentration of trace metals in Strombus canarium and comparison to other localities worldwide.

\begin{tabular}{|c|c|c|c|c|c|c|c|c|c|}
\hline \multirow{2}{*}{ Locations } & \multirow{2}{*}{ Species } & \multirow{2}{*}{ Values } & \multicolumn{6}{|c|}{ Dry Weight Fraction $(\mu \mathrm{g} / \mathrm{g})$} & \multirow{2}{*}{ Ref } \\
\hline & & & $\mathrm{Fe}$ & $\mathrm{Cu}$ & Co & $\mathrm{Pb}$ & Mn & $\mathrm{Ni}$ & \\
\hline \multirow{4}{*}{$\begin{array}{l}\text { Libong Island, } \\
\text { Thailand }\end{array}$} & \multirow{4}{*}{$\begin{array}{c}\text { Gastropod } \\
\text { (Strombus canarium) }\end{array}$} & Mean & 200.86 & 8.40 & 0.29 & 0.08 & 18.30 & 0.46 & \multirow{4}{*}{$\begin{array}{l}\text { This } \\
\text { study }\end{array}$} \\
\hline & & S.D. & 227.83 & 10.56 & 0.21 & 0.37 & 18.47 & 0.47 & \\
\hline & & Min & 0.00 & 0.00 & 0.00 & 0.00 & 0.00 & 0.00 & \\
\hline & & Max & 864.50 & 58.93 & 0.92 & 2.06 & 67.72 & 1.38 & \\
\hline Lake Manzala, Egypt & $\begin{array}{c}\text { Gastropod } \\
\text { (Lanistes carinatus) }\end{array}$ & Mean & 567.28 & 2.65 & 3.08 & 0.37 & 24.91 & 6.19 & [76] \\
\hline South India & $\begin{array}{l}\text { Gastropod } \\
\text { (Tibia curta) }\end{array}$ & Mean & 76.85 & 37.02 & 0.35 & 2.64 & 8.50 & 3.21 & [77] \\
\hline $\begin{array}{l}\text { North-Eastern } \\
\text { Mediterranean }\end{array}$ & $\begin{array}{c}\text { Gastropod } \\
\text { (Monodonta turbinata) }\end{array}$ & Mean & 3176.85 & 334.47 & 12.76 & 90.80 & 49.40 & 26.93 & [78] \\
\hline Red Sea coast & $\begin{array}{c}\text { Bivalve } \\
\text { (Tridacna maxima) }\end{array}$ & Mean & 600.00 & 39.73 & 1.63 & 33.66 & 41.77 & 38.88 & [79] \\
\hline $\begin{array}{l}\text { El-Mex, } \\
\text { Mediterranean coast }\end{array}$ & $\begin{array}{c}\text { Bivalve } \\
\text { (Mytilidae) }\end{array}$ & Mean & - & 11.85 & 4.25 & 0.43 & - & 14.95 & [80] \\
\hline $\begin{array}{l}\text { Marudu Bay, } \\
\text { Malaysia }\end{array}$ & $\begin{array}{c}\text { Bivalve } \\
\text { (Meretrix meretrix) }\end{array}$ & Mean & 285.50 & 74.90 & - & 2.77 & 20.30 & 4.23 & [81] \\
\hline
\end{tabular}




\subsection{Biota Sediment Accumulation Factor (BSAF)}

Gastropod mollusks are known to have the ability to absorb a wide range of pollutants from the environment and accumulate them in the body. This makes them good candidates for bioindicators to assess the levels of metal pollutants in an aquatic system. Thus, The BSAF was studied to evaluate the ability of these aquatic organisms to accumulate trace metals from the sediment, and the results are shown in Figure 3. The capacity of the Strombus canarium to bioaccumulate $\mathrm{Fe}, \mathrm{Cu}, \mathrm{Co}, \mathrm{Pb}, \mathrm{Mn}$, and $\mathrm{Ni}$ was $0.07,17.87,2.59$, $0.06,0.45$, and 0.17 , respectively. Based on $\mathrm{BSAF}$, for $\mathrm{Fe}, \mathrm{Pb}, \mathrm{Mn}$, and $\mathrm{Ni}$ this species could be classified as a de-concentrator $(\mathrm{BSAF}<1)$, whereas for $\mathrm{Cu}$ and $\mathrm{Co}$, the BSAF was higher than 2 , indicating a macro-concentrator. This suggests that the organism can accumulate metals in its soft tissue from sediment, and has difficult to excrete and release them. It is noted that Strombus canarium could be used as a bioindicator for $\mathrm{Cu}$ contamination. Among the marine organisms, high accumulation of $\mathrm{Cu}$ has also been found in some parts of molluscan tissues, especially those of marine gastropods [82] and bivalves [83,84]. There are many ways for accumulating and storing metals. These findings suggest that bioaccumulated $\mathrm{Cu}$ may be involved in metal-binding proteins, such as $\mathrm{Cu}$ metallothionein (MTs), and stored in lysosome [85]. Accumulation of metals in the tissues of a marine animal can reflect the metabolic demands for essential elements and the abundance of the elements in the environment. However, it not only depends on the level of the element in the environment, but also on various other factors, such as the rate of metal absorption, metabolic rate, physiology of digestion, season, species, body weight, age, and sex reproductive condition [86].

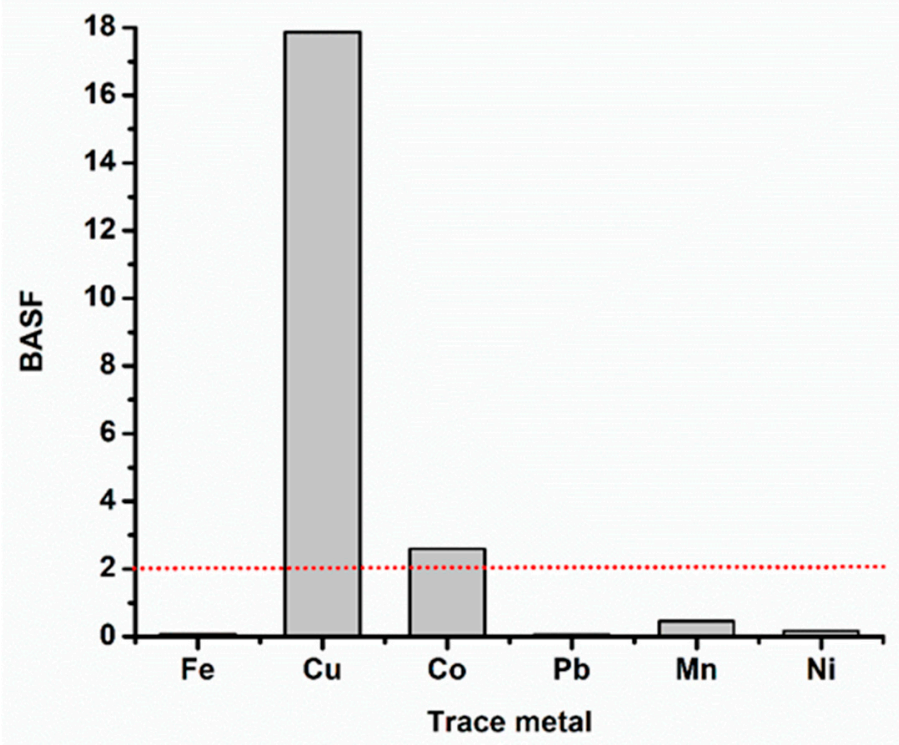

Figure 3. Biota sediment accumulation factors (BSAF) for Strombus canarium at Libong Island.

\subsection{The Relationship between Trace Metal Concentrations in Sediment and Soft Tissue of Shellfish}

Table 5 shows the correlation coefficients (r) between metal concentrations in sediment and soft tissue of shellfish. Significant positive correlation was observed between $\mathrm{Fe}$ and $\mathrm{Mn}(\mathrm{r}=0.770)$ as well as for $\mathrm{Cu}$ with $\mathrm{Co}(\mathrm{r}=0.390)$. It was found that trace metal concentrations in shellfish may be directly affected by those in the bottom sediment where these shellfish live. Our results agree with Aljahdali et al. (2020), who found significant correlations between metal in the sediment and in the snail [87]. 
Table 5. Correlation between metal concentrations in sediment and soft tissue of shellfish.

\begin{tabular}{ccccccc}
\hline & $\mathbf{F e}$ & $\mathbf{C u}$ & $\mathbf{C o}$ & $\mathbf{P b}$ & $\mathbf{M n}$ & $\mathbf{N i}$ \\
\hline $\mathrm{Fe}$ & 1 & & & & & \\
$\mathrm{Cu}$ & 0.279 & 1 & & & & \\
$\mathrm{Co}$ & -0.116 & $0.390^{*}$ & 1 & & & \\
$\mathrm{~Pb}$ & 0.310 & -0.063 & -0.272 & 1 & 1 & 1 \\
$\mathrm{Mn}$ & $0.770^{* *}$ & 0.283 & -0.015 & 0.061 & 0.084 & 1 \\
$\mathrm{Ni}$ & $0.073^{*}$ & -0.174 & -0.033 & 0.036 & 0.05 level (2-tailed).
\end{tabular}

\subsection{The Relationship between Trace Metal Concentrations in the Soft Tissues of Strombus canarium and Weight}

The weight of gastropod mollusk is an important factor that affects the metal accumulation rates in tissues [88]. The correlation coefficients between weight and trace metal concentrations of Strombus canarium are summarized in Table 6. The dry weight of Strombus canarium was in the range $0.14-2.53 \mathrm{~g}$ with the mean $0.75 \pm 0.58 \mathrm{~g}$. The results show that the weight of Strombus canarium was strongly positive correlated with $\mathrm{Fe}(\mathrm{r}=0.559)$ and $\mathrm{Mn}$ $(\mathrm{r}=0.426)$. Meanwhile, Fe also showed a positive correlation with $\mathrm{Mn}(\mathrm{r}=0.770)$ as well as with $\mathrm{Cu}$ and $\mathrm{Co}(\mathrm{r}=0.390)$. This shows that metal concentrations are greatly affected by the size of the organism. When the Strombus canarium is larger, the essential minerals, such as Fe and Mn, are accumulated at a higher level. In addition, the significant positive correlations between $\mathrm{Fe}$ and $\mathrm{Mn}$ and $\mathrm{Cu}$ and $\mathrm{Co}$ indicate that these metals might have been emitted from the same source or from the same parent materials. However, negative correlations among $\mathrm{Co}, \mathrm{Pb}, \mathrm{Ni}$, and weight were found in this study. One explanation may be the differences in metabolic activities between smaller and larger mollusks. In previous studies, several authors have suggested that the smaller and younger mollusks showed higher concentrations than the larger and older ones, which could be attributable to their higher metabolic rate [89]. In addition, Williamson (1980) suggested that an increased metabolic rate might affect the uptake and elimination of metals by their bodies [90].

Table 6. Correlation between metal concentrations in the soft tissues of Strombus canarium and dry weight.

\begin{tabular}{|c|c|c|c|c|c|c|c|}
\hline & Weight & $\mathrm{Fe}$ & $\mathrm{Cu}$ & Co & $\mathbf{P b}$ & Mn & $\mathrm{Ni}$ \\
\hline Weight & 1 & & & & & & \\
\hline $\mathrm{Fe}$ & $0.559 * *$ & 1 & & & & & \\
\hline $\mathrm{Cu}$ & 0.127 & 0.279 & 1 & & & & \\
\hline Co & -0.045 & -0.116 & $0.390 *$ & 1 & & & \\
\hline $\mathrm{Pb}$ & -0.042 & 0.310 & -0.063 & -0.272 & 1 & & \\
\hline $\mathrm{Mn}$ & 0.426 * & $0.770 * *$ & 0.283 & -0.015 & 0.061 & 1 & \\
\hline $\mathrm{Ni}$ & -0.086 & 0.073 & -0.174 & -0.033 & 0.036 & 0.084 & 1 \\
\hline
\end{tabular}

\subsection{Health Risk Assessment of the Trace Metals}

The estimated daily intake (EDI) from shellfish consumption was calculated (Table 7) based on the metal concentrations (by wet weight) in Strombus canarium and the daily food consumption. The EDI was calculated with the dietary intake guidelines recommended for Thai people who are 14-60 years of age (average body weight $=60 \mathrm{~kg}$ ). The EDI of Fe, $\mathrm{Cu}$, $\mathrm{Co}, \mathrm{Pb}, \mathrm{Mn}$, and Ni were 0.1175, 0.0049, 0.0002, 0.0001, 0.0107, and $0.0003 \mathrm{mg} / \mathrm{kg} \mathrm{bw} / \mathrm{day}$, respectively. As shown in Table 7 , the EDI of shellfish is lower than the oral reference dose (Rfd) guidelines for all trace elements studied. This strongly indicates that there is no health risk from the intake of trace metals by shellfish consumption. The THQ estimates no carcinogenic risk from this pollutant exposure. The THQ values for the targeted trace metals had the descending rank order $\mathrm{Fe}>\mathrm{Cu}>\mathrm{Mn}>\mathrm{Ni}>\mathrm{Pb}>\mathrm{Co}$. The THQ of each trace 
metal in shellfish was less than 1 , indicating that consumers of shellfish from this study area are not exposed to cancer hazards by that consumption.

Table 7. Estimated oral reference doses, estimated daily intakes, and target hazard quotients from shellfish consumption.

\begin{tabular}{ccccc}
\hline Metal & $\begin{array}{c}\text { Mean Metal } \\
\text { Concentration } \\
\text { (mg/kg) ww }\end{array}$ & $\begin{array}{c}\text { EDI (mg/kg } \\
\text { bw/day) }\end{array}$ & $\begin{array}{c}\text { Rfd (mg/kg } \\
\text { bw/day) }\end{array}$ & THQ \\
\hline $\mathrm{Fe}$ & 52.22 & 0.1175 & 0.70 & 0.1679 \\
$\mathrm{Cu}$ & 2.18 & 0.0049 & 0.04 & 0.1229 \\
$\mathrm{Co}$ & 0.08 & 0.0002 & 0.03 & 0.0057 \\
$\mathrm{~Pb}$ & 0.02 & 0.0001 & 0.004 & 0.0117 \\
$\mathrm{Mn}$ & 4.76 & 0.0107 & 0.14 & 0.0765 \\
$\mathrm{Ni}$ & 0.12 & 0.0003 & 0.02 & 0.0135 \\
\hline
\end{tabular}

EDI: the estimated daily intake; Rfd: the oral reference dose [39]; THQ: the target hazard quotients.

\section{Conclusions}

The purpose of this study was to assess trace metal contamination in the surface sediments and Strombus canarium samples collected from Libong Island. The mean metal concentrations in the sediments had the rank order $\mathrm{Fe}>\mathrm{Mn}>\mathrm{Ni}>\mathrm{Pb}>\mathrm{Cu}>\mathrm{Co}$. Trace metals in the sediments were found in the range from "no pollution" to "moderate potential ecological risks" in this study. The sources of most trace metals appeared natural, except for Mn, which had minor enrichment over what was expected naturally. The higher content of Mn was probably attributable to domestic waste and agricultural activities. However, all metal content in the sediments were still lower than thresholds in the sediment quality guidelines. The mean metal concentrations in Strombus canarium had the rank order $\mathrm{Fe}>\mathrm{Mn}>\mathrm{Cu}>\mathrm{Ni}>\mathrm{Co}>\mathrm{Pb}$. Based on BSAF index, Strombus canarium has potential for use in biomonitoring of $\mathrm{Cu}$. The correlation between soft tissue weight of Strombus canarium and trace metal concentration showed that the essential metals Fe and Mn bioaccumulated in mollusks, depending on body weight. Regarding concerns of human health risks, the EDI of trace metal from the targeted shellfish samples were calculated. It was found that EDI was below the reference dose according to the U.S. EPA. In addition, the THQs of individual elements were below 1 , suggesting that no health risk was posed to consumers. The data from this study provide valuable information about the current status of trace metal pollution, and can serve as a baseline for future studies in the region. However, investigations and monitoring should assess the long-term effects of trace metals in Libong Island and elsewhere in the Andaman Sea.

Author Contributions: Conceptualization, T.K. and S.P.; formal analysis, T.K., S.S., T.N. and D.M.; methodology, S.S., T.N., D.M., P.-S.L. and S.P.; supervision, S.P.; writing-original draft, T.K.; writingreview and editing, P.-S.L. and S.P. All authors have read and agreed to the published version of the manuscript.

Funding: This research was supported by Prince of Songkla University and the Ministry of Higher Education, Science, Research, and Innovation, Thailand, under the Reinventing University Project (grant number REV64030) and the Grand Challenges Thailand: Thai Ocean Waste Free, National Research Council of Thailand (sub project: marine litter and microplastic at Libong Island, Trang province).

Institutional Review Board Statement: All applicable international, national, and/or institutional guidelines for the care and use of animals were followed.

Informed Consent Statement: This study does not involve with human. The Strombus canarium samples were bought from the local people for con-sumption.

Data Availability Statement: The data that support the findings of this study are available from the authors upon reasonable request. 
Acknowledgments: We express great thanks to the Research Development Office (RDO/PSU) and Seppo Karrila for the English proofreading support.

Conflicts of Interest: The authors declare no conflict of interest.

\section{References}

1. Ali, H.; Khan, E.; Ilahi, I. Environmental chemistry and ecotoxicology of hazardous heavy metals: Environmental persistence, toxicity, and bioaccumulation. J. Chem. 2019, 2019, 6730305. [CrossRef]

2. Pandiyan, J.; Maboob, S.; Jagadheesan, R.; Elumalai, K.; Krishnappa, K.; Al-Misned, F.; Kaimkhani, Z.A.; Govindarajan, M. A novel approach to assess the heavy metal content in the feathers of shorebirds: A perspective of environmental research. J. King Saud Univ. Sci. 2020, 32, 3065-3071. [CrossRef]

3. Xia, C.; Zhang, X.; Xia, L. Heavy metal ion adsorption by permeable oyster shell bricks. Constr. Build. Mater. 2021, $275,122128$. [CrossRef]

4. Yang, J.; Chen, L.; Liu, L.-Z.; Shi, W.-L.; Meng, X.-Z. Comprehensive risk assessment of heavy metals in lake sediment from public parks in Shanghai. Ecotoxicol. Environ. Saf. 2014, 102, 129-135. [CrossRef]

5. US EPA. Framework for Metals Risk Assessment. EPA-120/R-07/001; U.S. Environmental Protection Agency, Office of the Science Advisor: Washington, DC, USA, 2007; pp. 1-172.

6. Pereira, P.; Korbas, M.; Pereira, V.; Cappello, T.; Maisano, M.; Canario, J.; Almeida, A.; Pacheco, M. A multidimensional concept for mercury neuronal and sensory toxicity in fish-From toxicokinetics and biochemistry to morphometry and behavior. $B B A$ Gen. Subj. 2019, 1863, 129298. [CrossRef]

7. WHO/FAO/IAEA. Trace Elements in Human Nutrition and Health; World Health Organization: Geneva, 1996; pp. 6-10.

8. Jaishankar, M.; Tseten, T.; Anbalgan, N.; Mathew, B.B.; Beeregowda, K.N. Toxicity, mechanism and health effects of some heavy metals. Interdiscip. Toxicol. 2014, 7, 60-72. [CrossRef] [PubMed]

9. Engwa, G.A.; Ferdinand, P.U.; Nwalo, F.N.; Unachukwu, M.N. Mechanism and health effects of heavy metal toxicity in humans. In Poisoning in the Modern World-New Tricks for an Old Dog? IntechOpen: London, UK, 2019; pp. 1-24.

10. Chon, H.-S.; Ohandja, D.-G.; Voulvoulis, N. The role of sediments as a source of metals in river catchments. Chemosphere 2012, 88, 1250-1256. [CrossRef]

11. Amin, B.; Ismail, A.; Arshad, A.; Yap, C.K.; Kamarudin, M.S. Anthropogenic impacts on heavy metal concentrations in the coastal sediments of Dumai, Indonesi. Environ. Monit. Assess. 2009, 148, 291-305. [CrossRef] [PubMed]

12. Naung, N. Distribution of the genus Strombus Linnaeus 1758 (Gastropoda: Strombidae) in some coastal areas of Myanmar. J. Aquac. Mar. Biol. 2018, 7, 258-263. [CrossRef]

13. Cob, Z.C.; Arshad, A.; Bujang, J.S.; Ghaffar, M.A. Seasonal variation in growth and survival of Strombus canarium (Linnaeus, 1758) larvae. Pak. J. Biol. Sci. 2009, 12, 676-682. [CrossRef] [PubMed]

14. Poutiers, J.M. Gastropods. In The Living Marine Resources of the Western Central Pacific; Carpenter, K.E., Niem, V.H., Eds.; FAO: Rome, Italy, 1998; pp. 363-646. ISBN 92-5-104051-6.

15. Kronenberg, G. Strombus (Canarium) Ochroglottis Betuleti a new subspecies from Sri Lanka with a short note on the distribution of S. (C.) Mutabilis Swainson, 1821. Gloria Maris 1991, 30, 53-58.

16. Nateewathana, A. Taxonomic account of commercially and edible mollusks, excluding cephalopods, of Thailand. Spec. Publ. Phuket Mar. Biol. Cent. 1995, 15, 93-116.

17. Hossen, F.M.; Hamdan, S.; Rahman, R.M. Cadmium and lead in blood cockle (Anadara granosa) from Asajaya, Sarawak. Malays. Sci. World J. 2014, 2014, 924360. [CrossRef] [PubMed]

18. Pradit, S.; Nitiratsuwan, T.; Towatana, P.; Jualaong, S.; Sornplang, K.; Noppradit, P.; Jirajarus, M.; Darakai, Y.; Weeerawong, C. Marine debris accumulation on the beach in Libong, a small island in Andaman sea, Thailand. Appl. Ecol. Environ. Res. 2020, 18, 5461-5474. [CrossRef]

19. US EPA. QA/QC Guidance for Sampling and Analysis of Sediments, Water, and Tissues for Dredged for Material Evaluations; EPA-823B95-001; U.S. Environmental Protection Agency, Office of the Science Advisor: Washington, DC, USA, 1995; pp. 1-144.

20. Pradit, S.; Wattayakorn, G.; Angsupanich, S.; Baeyens, W.; Leermakers, M. Distribution of trace elements in sediments and biota of Songkhla Lake, Southern Thailand. Water Air Soil Pollut. 2010, 206, 155-174. [CrossRef]

21. Zhao, W. Determination of six heavy metal elements such as Co in solid waste by ICP-MS. IOP Conf. Ser. Earth Environ. Sci. 2019, 300, 032108. [CrossRef]

22. Astatkie, H.; Ambelu, A.; Mengistie, E. Contamination of stream sediment with heavy metals in the Awetu watershed of Southwestern Ethiopia. Front. Earth Sci. 2021, 9, 658737. [CrossRef]

23. Pradit, S.; Shashili, N.A.M.; Towatana, P.; Saengmanee, W. Trace metals, grain size and organic matter in sediment from a coastal area of Thailand and Malaysia. Aquat Ecosyst. Health Manag. 2016, 19, 345-354. [CrossRef]

24. Salomons, W.; Förstner, U. Metals in the Hydrocycle; Springer: Berlin/Heidelberg, Germany; New York, NY, USA; Tokyo, Japan, 1984; pp. 1-360.

25. Ghrefat, H.A.; Abu-Rukah, Y.; Rosen, M.A. Application of geoaccumulation index and enrichment factor for assessing metal contamination in the sediments of Kafrain Dam, Jordan. Environ. Monit. Assess. 2011, 178, 95-109. [CrossRef] 
26. Shazili, N.A.M.; Rashid, M.K.A.; Husain, M.L.; Nordin, A.; Ali, S. Trace metals in the surface sediments of the South China Sea, area I: Gulf of Thailand and the East Coast of Peninsular Malaysia. In Proceedings of the First Technical Seminar on Marine Fishery Resources Survey in the South China Sea, Area I: Gulf of Thailand and East Coast of Peninsular Malaysia; Training Department, Southeast Asian Fisheries Development Center: Bangkok, Thailand, 1999; pp. 73-85.

27. Taylor, S.R.; McLennan, S.M. The geochemical evolution of the continental crust. Rev. Geophys. 1995, 33, 241-265. [CrossRef]

28. Kouidri, M.; Youcef, N.D.; Benabdellah, I.; Ghoubali, R.; Bernoussi, A.; Lagha, A. Enrichment and geoaccumulation of heavy metals and risk assessment of sediments from coast of Ain Temouchent (Algeria). Arab. J. Geosci. 2016, 9, 354. [CrossRef]

29. Shaari, H.; Azmi, S.N.H.; Sultan, K.; Bidai, J.; Mohamad, Y. Spatial distribution of selected heavy metals in surface sediments of the EEZ of the East Coast of Peninsular Malaysia. Int. J. Oceans Oceanogr. 2015, 2015, 618074. [CrossRef]

30. Muller, G. Index of geoaccumulation in the sediments of the Rhine River. GeoJournal 1969, 2, $108-118$.

31. Thongra-ar, W.; Musika, C.; Wongsudawan, W.; Munhapol, A. Heavy metals contamination in sediments along the Eastern Coast of the Gulf of Thailand. Environ. Asia 2008, 1, 37-45.

32. Islam, M.S.; Habibullah-Al-Mamun, M. Accumulation of trace elements in sediment and fish species of Paira River Bangladesh. AIMS Environ. Sci. 2017, 4, 310-322. [CrossRef]

33. Ju, Y.-R.; Chen, C.-W.; Chen, C.-F.; Chuang, X.-Y.; Dong, C.-D. Assessment of heavy metals in aquaculture fishes collected from southwest coast of Taiwan and human consumption risk. Int. Biodeter. Biodegr. 2017, 124, 314-325. [CrossRef]

34. Dallinger, R. Strategies of metal detoxification in terrestrial invertebrates. Ecotoxicology of Metal in Invertebrates; Dallinger, R., Rainbow, P.S., Eds.; Lewis Publishers: Boca Raton, FL, USA, 1993; pp. 246-289.

35. Yap, C.K.; Wong, K.W.; Al-shami, S.A.; Nulit, R.; Cheng, W.H.; Aris, A.Z.; Sharifinia, M.; Bakhtiari, A.R.; Okamura, H.; Saleem, M.; et al. Human Health risk assessments of trace metals on the clam Corbicula javanica in a tropical river in Peninsular Malaysia. Int. J. Environ. Res. Public Health 2021, 18, 195. [CrossRef]

36. Khandaker, M.U.; Asaduzzaman, K.h.; Nawi, S.M.; Usman, A.R.; Amin, Y.M.; Daar, E.; Bradley, D.A.; Ahmed, H.; Okhunov, A.A. Assessment of radiation and heavy metals risk due to the dietary intake of marine fishes (Rastrelliger kanagurta) from the Straits of Malacca. PLoS ONE 2015, 10, e0128790. [CrossRef]

37. Rangkadilok, N.; Siripriwon, P.; Nookabkaew, S.; Suriyo, T.; Satayavivad, J. Arsenic, cadmium, and manganese levels in shellfish from Map Ta Phut, an industrial area in Thailand, and the potential toxic effects on human cells. Arch. Environ. Contam. Toxicol. 2015, 68, 169-180. [CrossRef]

38. Zhao, L.; Yang, F.; Yan, X. Concentrations of selected trace elements in marine bivalves and the dietary risk to residents of Dalian City, Northern China. Hum. Ecol. Risk Assess. 2013, 19, 145-150. [CrossRef]

39. US EPA Regional Screening Level (RSL) Summary Table: November 2011. Available online: http://www.epa.gov / / regshwmd/ risk/human/Index.htm (accessed on 20 January 2014).

40. Yao, G.; Xiaoming, S.; Xiaodong, J.; Rina, S.; Li, Z.; Yi, H.; Yating, L.; Xiaojie, L.; Rongfei, L.; Chi, W. The effect of Fe-Mn minerals and seawater interface and enrichment mechanism of ore-forming elements of polymetallic crusts and nodules from the South China Sea. Acta Oceanol. Sin. 2017, 36, 34-46.

41. Ranibar Jafarabadi, A.; Riyahi Bakhtiari, A.; Maisano, M.; Pereira, P.; Cappello, T. First record of bioaccumulation and bioconcentration of metals in Scleractinian corals and their algal symbionts from Kharg and Lark coral reefs (Persian Gulf, Iran). Sci. Total Environ. 2018, 640-641, 1500-1511. [CrossRef]

42. Ranibar Jafarabadi, A.; Riyahi Bakhtiari, A.; Spano, N.; Capello, T. First report of geochemical fractionation distribution, bioavailability and risk assessment of potentially toxic inorganic elements in sediments of coral reef Islands of the Persian Gulf, Iran. Mar. Pollut. Bull. 2018, 137, 185-197. [CrossRef] [PubMed]

43. Perumal, K.; Antony, J.; Muthuramalingam, S. Heavy metal pollutants and their spatial distribution in surface sediments from Thondi coast, Palk Bay. South India. Environ. Sci. Eur. 2021, 33, 63. [CrossRef]

44. Cai, P.; Cai, G.; Chen, X.; Li, S.; Zhao, L. The concentration distribution and biohazard assessment of heavy metal elements in surface sediments from the continental shelf of Hainan Island. Mar. Pollut. Bull. 2021, 166, 112254. [CrossRef] [PubMed]

45. El-Sorogy, A.; Al-Kahtany, K.; Youssef, M.; Al-Kahtany, F.; Al-Malky, M. Distribution and metal contamination in the coastal sediments of Dammam Al-Jubail area, Arabian Gulf, Saudi Arabia. Mar. Pollut. Bull. 2018, 128, 8-16. [CrossRef]

46. Liu, S.; Shi, X.; Yang, G.; Khokiattiwong, S.; Kornkanitnan, N. Concentration distribution and assessment of heavy metals in the surface sediments of the western Gulf of Thailand. Environ. Earth Sci. 2016, 75, 346. [CrossRef]

47. Yang, Q.; Hu, G.; Yu, R.; He, H.; Lin, C. Distribution, fractionation, and contamination assessment of heavy metals in offshore surface sediments from western Xiamen Bay, China. Acta Geochim. 2016, 35, 355-367. [CrossRef]

48. Liu, X.; Jiang, X.; Liu, Q.; Teng, A.; Xu, W. Distribution and pollution assessment of heavy metals in surface sediments in the central Bohai Sea, China: A case study. Environ. Earth Sci. 2016, 75, 364. [CrossRef]

49. Potipat, J.; Tangkrock-Olan, N.; Helander, H.F. Bioconcentration factor (BCF) and depuration of heavy metals of oysters (Saccostrea cucullata) and mussels (Perna viridis) in the river basins of coastal area of Chanthaburi Province, Gulf of Thailand. Environ. Asia 2015, 8, 118-128.

50. Okbah, M.A.; Nasr, S.M.; Soliman, N.F.; Khairy, M.A. Distribution and contamination status of trace metals in the mediterranean coastal sediments, Egypt. Soil Sediment Contam. 2014, 23, 656-676. [CrossRef]

51. Salem, D.M.S.A.; Khaled, A.; El Nemr, A.; El-Sikaily, A. Comprehensive risk assessment of heavy metals in surface sediments along the Egyptian Red Sea coast. Egypt. J. Aquat. Res. 2014, 40, 349-362. [CrossRef] 
52. Tayakoly Sany, S.B.; Salleh, A.; Rezayi, M.; Saadati, N.; Narimany, L.; Tehrani, G.M. Distribution and contamination of heavy metal in the coastal sediments of port Klang, Selangor, Malaysia. Water Air Soil Pollut. 2013, 224, 1476. [CrossRef]

53. Ünlü, S.; Topçuoğlu, S.; Alpar, B.; Kırbaşoğlu, C.; Yılmaz, Y.Z. Heavy metal pollution in surface sediment and mussel samples in the Gulf of Gemlik. Environ. Monit. Assess. 2008, 144, 169-178. [CrossRef]

54. Duarte, C.M.; Martín, M.; Margarita, G. Evidence of iron deficiency in seagrasses growing above carbonate sediments. Limnol. Oceanogr. 1995, 40, 1153-1158. [CrossRef]

55. Tahril; Taba, P.; la Nafie, N.; Noor, A.; Ratna; Muzakkar, M.Z. Iron, manganese and copper metals in seagrass ecology in Donggala district, Indonesia. Asian J. Appl. Sci. 2020, 13, 1-7.

56. Filho, G.M.A.; Creed, J.C.; Andrade, L.R.; Pfeiffer, W.C. Metal accumulation by Halodule wrightii populations. Aquat. Bot. 2004, 80, 241-251. [CrossRef]

57. Thangaradjpu, T.; Nobi, E.P.; Dilipan, E.; Sivakumar, K.; Susila, S. Heavy metal enrichment in seagrasses of Andaman Islands and its implication to the health of the coastal ecosystem. Indian J. Mar. Sci. 2010, 39, 85-91.

58. Chen, Y.-M.; Gao, J.-B.; Yuan, Y.-Q.; Ma, J.; Yu, S. Relationship between heavy metal contents and clay mineral properties in surface sediments: Implications for metal pollution assessment. Cont. Shelf Res. 2016, 124, 125-133. [CrossRef]

59. US EPA. Guidance for the Pollution Classification of Great Lakes Harbor Sediments; U.S. Environmental Protection Agency: Chicago, IL, USA, 1997; pp. 1-8.

60. NOAA. Sediment Quality Guidelines Developed for the National Status and Trends Program. 1999. Available online: http: / / response.restoration.noaa.gov/book_shelf/121_sedi_qual_guide.pdf (accessed on 20 July 2010).

61. MacDonald, D.D.; Ingersoll, C.G.; Berger, T.A. Development and evaluation of consensus-based sediment quality guidelines for freshwater ecosystems. Arch. Environ. Con. Tox. 2000, 39, 20-31. [CrossRef]

62. Zhang, J.; Liu, C.L. Riverine composition and estuarine geochemistry of particulate metals in China-weathering features, anthropogenic impact and chemical fluxes. Estuar. Coast. Shelf Sci. 2002, 54, 1051-1070. [CrossRef]

63. Boudissa, S.M.; Lambert, J.; Mu“ller, C.; Kennedy, G.; Gareau, L.; Zayed, J. Manganese concentrations in the soil and air in the vicinity of a closed manganese alloy production plant. Sci. Total Environ. 2006, 361, 67-72. [CrossRef] [PubMed]

64. Zhang, Y.; Meng, Q.; Jiang, T.; Wang, H.; Xie, L.; Zhang, R. A novel ferritin subunit involved in shell formation from the pearl oyster (Pinctada fucata). Comp. Biochem. Physiol. B 2003, 135, 43-54. [CrossRef]

65. Bai, Z.; Yuan, Y.; Yue, G.; Li, J. Molecular cloning and copy number variation of a ferritin subunit (Fth1) and its association with growth in freshwater pearl mussel Hyriopsis cumingii. PLoS ONE 2011, 6, e22886. [CrossRef] [PubMed]

66. Chen, P. Manganese metabolism in humans. Front. Biosci. 2018, 23, 1655-1679. [CrossRef]

67. Albretsen, J. The toxicity of iron, an essential element. Vet. Med. 2006, 101, 82-90.

68. Forti, E.; Salovaara, S.; Cetin, Y.; Bulgheroni, A.; Tessadri, R.; Jennings, P.; Prieto, P. In vitro evaluation of the toxicity induced by nickel soluble and particulate forms in human airway epithelial cells. Toxicol. In Vitro 2011, 25, 454-461. [CrossRef]

69. Saha, N.; Zaman, M.R. Evaluation of possible health risks of heavy metals by consumption of foodstuffs available in the central market of Rajshahi City Bangladesh. Environ. Monit. Assess. 2013, 185, 3867-3878. [CrossRef]

70. Angeloval, M.; Asenova, S.; Nedkova, V.; Koleva-Kolarova, R. Copper in the human organism. Trakia J. Sci. 2011, 9, 88-98.

71. Attri, S.; Sharma, N.; Jahagirdar, S.; Thapa, B.R.; Prasad, R. Erythrocyte metabolism and antioxidant status of patients with Wilson disease with hemolytic anemia. Pediatr. Res. 2006, 59, 593-597. [CrossRef]

72. Sheikh, I. Cobalt poisoning: A comprehensive review of the literature. Int. J. Med. Toxicol. Forensic Med. 2016, 2, 1-6. [CrossRef]

73. Ismail, T.H.T.; Adnan, N.A.F.; Samah, M.A.A. Study on accumulation of Fe, Pb, Zn, Ni and Cd in Nerita lineata and Thais bitubercularis from Tanjung Harapan and Teluk Kemang, Malaysia. J. Clean WAS 2017, 1, 6-16. [CrossRef]

74. García-lestón, J.; Mendez, J.; Pásaro, E.; Laffon, B. Author's personal copy genotoxic effects of lead: An updated review. Environ. Int. 2010, 36, 623-636. [CrossRef]

75. Sabri, S.; Said, M.I.M.; Azman, S. Lead (Pb) And Zinc ( $\mathrm{Zn})$ concentrations in marine gastropod Strombus canarium in Jahor coastal areas. Malays. J. Anal. Sci. 2014, 18, 37-42.

76. Abdel Gawad, S.S. Concentrations of heavy metals in water, sediment and mollusk gastropod, Lanistes carinatus from Lake Manzala, Egypt. Egypt. J. Aquat. Res. 2018, 44, 77-82. [CrossRef]

77. Ragi, A.S.; Leena, P.P.; Cheriyan, E.; Nair, S.M. Heavymetal concentrations in some gastropods and bivalves collected from the fishing zone of South India. Mar. Pollut. Bull. 2017, 118, 452-458. [CrossRef]

78. Duysak, Ö.; Ersoy, B. A Biomonitoring study: Heavy metals in Monodonta turbinate (Mollusca: Gastropoda) from Iskenderun bay, North-Eastern Mediterranean. Pakistan J. Zool. 2014, 46, 1317-1322.

79. Madkour, H.A. Distribution and relationships of heavy metals in the giant clam (Tridacna mamima) and associated sediments from different sites in the Egyptian Red Sea Coast. Egypt. J. Aquat. Res. 2005, 31, 45-59.

80. El Nemr, A.; Khaled, A.; Moneer, A.A.; Sikaily, A.E. Risk probability due to heavy metals in bivalve from Egyptian Mediterranean coast. Egypt. J. Aquat. Res. 2012, 38, 67-75. [CrossRef]

81. Denil, D.J.; Fui, C.F.; Ransangan, J. Health risk assessment due to heavy metals exposure via consumption of bivalves harvested from Marudu Bay, Malaysia. Open J. Mar. Sci. 2017, 7, 494-510. [CrossRef]

82. Liang, L.N.; He, B.; Jiang, G.B.; Chen, D.Y.; Yao, Z.W. Evaluation of mollusks as biomonitors to investigate heavy metal contaminations along the Chinese Bohai Sea. Sci. Total Environ. 2004, 324, 105-113. [CrossRef] [PubMed] 
83. Rzymski, P.; Niedzielski, P.; Klimaszyk, P.; Poniedzialek, B. Bioaccumulation of selected metals in bivalves (Unionidae) and Phragmites australis inhabiting a municipal water reservoir. Environ. Monit. Assess. 2014, 186, 3199-3212. [CrossRef] [PubMed]

84. Nourozifard, P.; Mortazavi, S.; Asad, S.; Hassanzadeh, N. Using Saccostrea cucullata as a biomonitor of heavy metals (Cu, Pb, Zn, $\mathrm{Cd}, \mathrm{Ni}$, and $\mathrm{Cr}$ ) in water and sediments of Qeshm Island, Persian Gulf. Ecopersia 2020, 8, 181-190.

85. Nam, Y.K.; Kim, E.J. Diversification and domain evolution of molluskan metallothioneins: A mini review. Fish. Aquatic Sci. 2017, 20, 2-18. [CrossRef]

86. Samsi, A.N.; Karim, S. The relationship between the length and weight of snail Nerita lineata Gmelin 1791 on environmental factors in the mangrove ecosystem. J. Phys. Conf. Ser. 2019, 1341, 022022. [CrossRef]

87. Aljahdali, M.O.; Alhassan, A.B. Spatial variation of metallic contamination and its ecological risk in sediment and freshwater mollusk: Melanoides tuberculata (Müller, 1774) (Gastropoda: Thiaridae). Water 2020, 12, 206. [CrossRef]

88. Łuczyńska, J.; Tońska, E.; Paszczyk, B.; Łuczyński, M.J. The relationship between biotic factors and the content of chosen heavy metals ( $\mathrm{Zn}, \mathrm{Fe}, \mathrm{Cu}$ and $\mathrm{Mn}$ ) in six wild freshwater fish species collected from two lakes (Łańskie and Pluszne) located in northeastern Poland. Iran. J. Fish. Sci. 2020, 19, 421-442.

89. Yap, C.K.; Ismail, A.; Tan, S.G. Effect of body size on heavy metal contents and concentrations in green-lipped mussel perna viridis (Linnaeus) from Malaysian coastal waters. Pertanika J. Sci. Technol. 2009, 17, 61-68.

90. Williamson, P. Variables affecting body burdens of lead, zinc and cadmium in a roadside population of the snail Cepaea hortensis muller. Oecologia 1980, 44, 213-220. [CrossRef] 